\title{
Pengembangan Sistem Pakar Untuk Diagnosis Penyakit Hepatitis Berbasis Web Menggunakan Metode Certainty Factor
}

\author{
Ahmad Ramdhani $^{1)}$, R. Rizal Isnanto ${ }^{2)}$, Ike Pertiwi Windasari ${ }^{2)}$ \\ Program Studi Sistem Komputer Fakultas Teknik Universitas Diponegoro \\ Jalan Prof. Sudharto, Tembalang, Semarang, Indonesia \\ ahmdrmdhni@gmail.com
}

\begin{abstract}
Expert System is a computer technology that can help people solving problems which are mostly applied in medicine. Expert System is system that trying to adopt human knowledge to the computer, so the computer can resolve the issue as done by an expert.. In this study, an Expert System to diagnose hepatitis disease consisting of Hepatitis A, Hepatitis B, and Hepatitis $C$ will be created.

This expert system to diagnose hepatitis disease is created using PHP programing language and MySQL database using Certainty Factor method. This expert system will ask for an input such as symtomps and blood test, then the result is the possibility of the disease suffered by the patient and an explanation of the disease and its treatment solution.

This expert system is able to issue diagnosis results for Hepatitis A, Hepatitis B, and Hepatitis C.. Certainty Factor method can be applied to expert systems with simple disease or not complex, such as acute hepatitis disease that is done in this study.
\end{abstract}

Keywords : Expert System, Hepatitis, PHP, MySQL, Certainty Factor

\section{PENDAHULUAN}

Perkembangan teknologi informasi dewasa ini sangat pesat. Hampir semua bidang terpengaruh oleh perkembangan ini, salah satunya adalah bidang kesehatan. Hal ini mendorong para ahli untuk semakin mengembangkan komputer agar dapat membantu kerja manusia. Sistem pakar adalah program berbasis pengetahuan yang menyediakan solusi-solusi dengan kualitas pakar untuk masalah-masalah yang spesifik. Sistem pakar merupakan sistem yang berusaha mengadopsi pengetahuan manusia ke komputer, agar komputer dapat menyelesaikan masalah seperti yang biasa dilakukan oleh para ahli, atau dengan kata lain sistem pakar adalah sistem yang didesain dan diimplementasikan dengan bantuan bahasa pemrograman tertentu untuk dapat menyelesaikan masalah seperti yang dilakukan oleh para ahli. Selain itu, sistem pakar juga dapat memberikan hasil yang lebih konsisten daripada pakar. Sistem pakar dapat melakukan pengambilan kesimpulan lebih cepat daripada pakar. ${ }^{[1]}$

Metode pengambilan keputusannya beragam. Ada yang menggunakan operasi logika dan ada yang menggunakan teori perhitungan pengambilan keputusan seperti certainty factor. Dibandingkan teori atau metode yang lainnya certainty factor memiliki keakuratan yang lebih karena cara perhitungannya yang hanya dapat membandingkan tiap dua nilai saja. ${ }^{[7]}$

Hepatitis merupakan penyakit yang menyerang organ hati manusia. Di sini hati atau liver mengalami peradangan sehingga membuat fungsi hati menjadi terganggu. Dengan terganggunya fungsi hati tersebut, maka terganggu pula fungsi organ yang lain, sehingga membuat kesehatan seseorang akan hancur secara keseluruhan. Akibat lainnya adalah hati menolak darah yang mengalir sehingga tekanan darah menjadi tinggi dan pecahnya pembuluh darah. Ada 5 macam virus hepatitis yang dinamai sesuai abjad. Kelima virus itu adalah Virus Hepatitis A (VHA), Virus Hepatitis B (VHB), Virus Hepatitis C (VHC), Virus Hepatitis D (VHD), dan Virus Hepatitis E (VHE). Gejala-gejala umum dari hepatitis ini adalah rasa nyeri atau sakit pada perut bagian kanan, badan lemas, mual, demam dan diare. Pada beberapa kasus juga ditemukan gejala seperti akan flu dan sakit kuning yang ditandai kulit dan mata yang terlihat kuning. Namun, gejala penyakit hepatitis tidak selalu tampak, khususnya pada kebanyakan kasus yang menimpa anak-anak. ${ }^{[5]}$

Berdasarkan latar belakang di atas, maka diperlukan sebuah sistem pakar untuk melakukan diagnosis penyakit hepatitis dan memberikan hasil yang konsisten. Sebelumnya sudah ada yang melakukan penelitian tentang sistem pakar hepatitis ini diantaranya adalah "Aplikasi Diagnosis Penyakit Hepatitis Menggunakan J2ME Dengan Metode Certainty Factor" oleh Susanto $\mathrm{H}^{[6]}$, serta "Rancang Bangun Aplikasi Diagnosa Penyakit Hepatitis Menggunakan Certainty Factor" oleh Pramana $\mathrm{E}^{[3]}$. Proses diagnosis dari kedua penelitian tersebut sama sama menggunakan dua acuan yaitu gejala dan hasil tes darah. Proses diagnosis suatu penyakit seharusnya ditinjau dari faktor risiko, gejala, dan hasil uji tes darah. Dalam pemilihan gejala kedua penelitian tersebut tidak memberikan penjelasan tentang gejala tersbut. Kemudian hasil diagnosis dari kedua penelitian tersebut sama sama memeberikan nilai kemungkinan terkena penyakit. Salah satu kelebihan dari Sistem Pakar yang dibuat oleh Pramana E adalah penyajian meal plan untuk aksi tiap tiap penyakit yang diderita.

Oleh karena itu penulis bermaksud untuk merancang suatu sistem pakar yang mampu melakukan diagnosis serta memberikan solusi yang tepat terhadap penyakit Hepatitis 
dengan menggunakan faktor risiko, gejala, dan hasil uji tes darah sebagai acuannya. Tentunya dengan cara penyajian dan data nilai kemungkinan yang berbeda dari kedua penelitian yang disebutkan sebelumnya. Bagi masyarakat sistem ini dapat digunakan untuk pengecekan awal apakah terserang penyakit hepatitis sebelum berobat ke dokter. Sistem ini juga dapat dijadikan media pembelajaran tentang penyakit hepatitis.

\section{RUMUSAN MASALAH}

Rumusan masalah dari penelitian ini adalah:

a) Bagaimana merancang dan membangun sistem pakar yang mampu mendiagnosis penyakit Hepatitis secara mudah dan dapat memberikan keterangan beserta solusinya?

b) Bagaimana mengimplementasikan metode Certainty Factor ke dalam sistem pakar sehingga menghasilkan keputusan yang valid?

\section{BATASAN MASALAH}

Dalam penulisan tugas akhir ini, penulis membatasi pembahasan dalam hal berikut.

a) Penyakit hepatitis yang akan didiagnosis adalah Hepatitis A, Hepatitis B, dan Hepatitis C. Diagnosis penyakit berdasarkan gejala-gejala yang dialami serta hasil tes darah untuk keakuratan diagnosis.

b) Pengguna lebih ditujukan untuk Dokter atau Petugas Medis di bidang Penyakit Dalam tetapi tidak menutup kemungkinan masyarakat juga dapat menggunakan sistem.

c) Aplikasi dibuat menggunakan bahasa pemrograman PHP dengan database MySQL.

d) Sistem Pakar lebih ditekankan pada penerapan metode Certainty Factor untuk perhitungan kepastian.

e) Sumber pengetahuan terbatas dari pakar dan buku-buku yang mendukung.

\section{TUJUAN}

Tujuan dari penilitian dari tugas akhir ini adalah sebagai berikut.

a) Merancang dan membangun sistem pakar untuk mendiagnosis penyakit hepatitis $\mathrm{A}$, hepatitis $\mathrm{B}$, dan hepatitis C.

b) Memberikan hasil diagnosis penyakit beserta keterangan dan solusi yang benar dan tepat.

\section{LANDASAN TEORI}

\section{A. Kecerdasan Buatan}

Kecerdasan Buatan adalah ide-ide untuk membuat suatu perangkat lunak komputer yang memiliki kecerdasan sehingga perangkat lunak komputer tersebut dapat melakukan suatu pekerjaan yang dilakukan oleh manusia. Adapun pekerjaan itu adalah berupa konsultasi yang dapat memberikan suatu informasi berupa saran-saran yang akan sangat berguna. Kecerdasan Buatan memungkinkan komputer untuk berpikir dengan cara menyederhanakan program. Dengan cara ini, Kecerdasan Buatan dapat menirukan proses belajar manusia sehingga informasi baru dapat diserap dan digunakan sebagai acuan di masa-masa mendatang. Sesuai dengan definisi tersebut, maka teknologi kecerdasan buatan dipelajari dalam bidang-bidang seperti: Robotika (Robotics), Penglihatan Komputer (Computer Vision), Pengolahan Bahasa Alami (Natural Language Processing), Pengenalan Pola (Pattern Recognition), Sistem Syaraf buatan (Artificial Neural System), Pengenalan Suara (Speech Recognition), dan Sistem Pakar (Expert System). ${ }^{[1] .}$

\section{B. Sistem Pakar}

Sistem pakar adalah sistem yang berusaha mengadopsi pengetahuan manusia ke komputer, agar komputer dapat menyelesaikan masalah seperti yang bisa dilakukan oleh para ahli. Adanya sistem pakar ini, orang awam pun dapat menyelesaikan masalah yang cukup rumit yang sebenarnya hanya dapat diselesaikan dengan bantuan para ahli. ${ }^{[1]}$

Sistem pakar terdiri dari 3 komponen utama, yaitu : antarmuka pengguna, basis pengetahuan, mesin inferensi. Untuk lebih jelasnya, diagram blok umum sistem pakar dapat dilihat pada gambar dibawah ini :

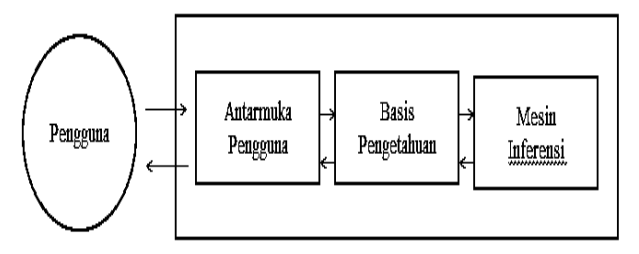

Gambar 1 Diagram blok umum sistem pakar

\section{Certainty Factor}

Faktor Kepastian(Certainty Factor) model adalah metode untuk mengelola ketidakpastian dalam sistem berbasis aturan. Shortliffe dan Buchanan (1975) mengembangkan model CF di pertengahan 1970-an untuk MYCIN, sebuah sistem pakar untuk diagnosis dan pengobatan meningitis dan infeksi darah. Sejak itu, model CF telah menjadi pendekatan standar untuk manajemen ketidakpastian dalam sistem berbasis aturan. Ketika model diciptakan, banyak buatan-kecerdasan (AI) peneliti mengungkapkan con-cern tentang menggunakan Bayesian (atau subyektif) probabilitas untuk mewakili ketidakpastian. Dari jumlah tersebut peneliti, yang paling khawatir tentang batasan praktis menggunakan teori probabilitas. ${ }^{[7]}$

Certainty Factor didefinisikan sebagai persamaan berikut :

$\mathrm{CF}(\mathrm{H}, \mathrm{E})=\mathrm{MB}(\mathrm{H}, \mathrm{E})-\mathrm{MD}(\mathrm{H}, \mathrm{E})$

$\mathrm{CF}(\mathrm{H}, \mathrm{E})$ : Certainty Factor dari hipotesis $\mathrm{H}$ yang dipengaruhi oleh gejala E. Besarnya CF berkisar antara -1 sampai 1. Nilai -1 menunjukkan ketidakpercayaan mutlak sedangkan nilai 1 menunjukkan kepercayaan mutlak.

MB (H,E) :ukuran kenaikan kepercayaan (measure of increased belief) terhadap hipotesis $\mathrm{H}$ yang dipengaruhi oleh gejala E.

MD (H,E) :ukuran kenaikan ketidakpercayaan terhadap hipotesis $\mathrm{H}$ yang dipengaruhi oleh gejala $\mathrm{E}$. 
Certainty Factor untuk kaidah dengan kesimpulan yang serupa (similarly concluded rules) :

$$
\text { CFcombine } \mathrm{CF}[\mathrm{H}, \mathrm{E}]_{1,2}=\mathrm{CF}[\mathrm{H}, \mathrm{E}]_{1}+\mathrm{CF}[\mathrm{H}, \mathrm{E}]_{2} *(1-
$$

\section{$\left.\mathrm{CF}[\mathrm{H}, \mathrm{E}]_{1}\right)$}

Jika nilai CF yang akan dihitung lebih dari dua

didefiniskan dengan persamaan berikut :

CFcombine $\mathrm{CF}[\mathrm{H}, \mathrm{E}]_{\mathrm{old}, 3}=\mathrm{CF}[\mathrm{H}, \mathrm{E}]_{\mathrm{old}}+\mathrm{CF}[\mathrm{H}, \mathrm{E}]_{3} *$ $\left(1-\mathrm{CF}[\mathrm{H}, \mathrm{E}]_{\text {old }}\right)$

\section{Penyakit Hepatitis}

Hepatitis adalah peradangan pada hati. Penyebab tersering dari Hepatitis adalah: virus, infeksi bakteri, toksin, obat-obatan tertentu, penggunaan alkohol yang berlebihan serta penyakit lainnya. Virus hepatitis merupakan bagian dari keluarga virus A, B, C, D dan E. Semua jenis hepatitis memiliki gejala yang sama: demam, menggigil, kehilangan nafsu makan/anorexia, mual, rasa tidak nyaman pada perut, penyakit kuning (kuning pada kulit dan mata), dan nyeri sendi. Tidak diperlukan adanya penanganan khusus. Kebanyakan orang akan sembuh dengan sendirinya selama berjalannya waktu. Namun beberapa infeksi bisa menyebabkan masalah kronis jangka panjang. ${ }^{[5]}$

Virus hepatitis A adalah suatu penyakit dengan distribusi global. Prevalensi inveksi yang ditandai dengan tingkatan antibodi dan anti-HAV telah diketahui secara universal dan erat hubungannya dengan standar sanitasi/kesehatan daerah yang bersangkutan. Meskipun virus hepatitis A ditularkan melalui air dan makanan yang tercemar, namun hampir sebagian besar infeksi VHA didapat melalui transmisi endemik atau sporadik yang sifatnya tidak begitu dramatis. ${ }^{[5]}$

Infeksi virus hepatitis B (VHB) masih merupakan masalah yang besar di Indonesia karena prevalensi yang tinggi dan komplikasinya. Di daerah dengan endemik tinggi, infeksi VHB biasanya terjadi melalui infeksi perinatal atau pada awal masa kanak-kanak. VHB sendiri biasanya tidak sitopatik. Infeksi kronik VHB merupakan suatu proses dinamis dengan terjadi interaksi antara cvirus, hepatosit dan sistem imun manusia. ${ }^{[5]}$

Sejak berhasil ditemukannya virus hepariris C dengan teknik cloning molekuler di tahin 1989, sejumlah perkembangan yang bermakna telah terjadi dalam pemahaman mengenai perjalanan alamiah, diagnosis dan terapi infeksi virus hepatitis C. Dahulu kita hanya dikeal virus ini sebgai infeksi virus hepatitis non-A dan non-B, namun saat ini telah diketahui bahwa infeksi yang hanya memilikai tanda-tanda subklinin ringan ini ternyata memiliki tingkat krinisitas dan progresifitas kearah sirosis yang tinggi. [5]

\section{E. Bahasa Pemrograman PHP}

PHP adalah akronim dari Hypertext Preprocessor, yaitu suatu bahasa pemrograman berbasiskan kode - kode ( script) yang digunakan untuk mengolah suatu data dan mengirimkannya kembali ke web browser menjadi kode HTML. Kode PHP mempunyai ciri khusus yaitu ${ }^{[2]}$ :

1. Hanya dapat dijalankan menggunakan web server, misalnya Apache.
2. Kode PHP diletakkan dan dijalankan di web server.

3. Kode PHP dapat digunakan untuk mengakses database, seperti : MySQL, PostgreSQL, Oracle, dan lain - lain.

4. Merupakan perangkat lunak yang bersifat open source.

5. Gratis untuk di-download dan digunakan.

Memiliki sifat multi platform, artinya dapat dijalankan menggunakan system operasi apapun, seperti: Linux, Unix, Windows, dan lain - lain.

\section{F. Database MYSQL}

MySQL merupakan sistem database yang menggunakan arsitektur client-server yang berpusat pada server, mysqld. Server adalah program yang sebenarnya memanipulasi database. Program klien tidak melakukannya secara langsung. Namun, klien menyampaikan instruksi kita ke server melalui pernyataan yang ditulis dalam Structured Query Language (SQL). Program klien di-install secara lokal pada mesin di mana kita ingin mengakses MySQL, namun server dapat di-install di manapun, selama klien dapat terkoneksi dengannya. MySQL pada dasarnya merupakan sistem database pada jaringan, sehingga klien dapat berkomunikasi dengan server yang berjalan secara lokal pada mesin kita atau server yang berjalan di suatu tempat lain. Klien dapat ditulis untuk berbagai kebutuhan berbeda, tiap interaksi dengan server melewati koneksi dengan server, mengirim perintah SQL untuk melakukan operasi database, dan menerima hasil eksekusi perintah tersebut darinya. ${ }^{[4]}$.

\section{PERANCANGAN SISTEM}

\section{A. Tahapan Pengembangan}

1. Konsep

Kebutuhan-kebutuhan yang harus dimiliki oleh sistem yang akan dikembangkan dikelompokkan menjadi kebutuhan fungsional dan kebutuhan non fungsional. Identifikasi masing-masing kebutuhan bagi sistem menghasilkan keterangan berikut.

Kebutuhan Fungsional :

1. Sistem dapat melakukan diagnosis penyakit hepatitis A, hepatitis B, dan Hepatitis C melalui menu konsultasi.

2. Sistem memiliki fitur login untuk admin agar tidak semua pengguna dapat mengakses basis data.

3. Admin dapat mengelola data gejala penyakit yang digunakan sebagai masukan untuk diagnosis penyakit.

4. Admin dapat mengelola data penyakit.

5. Admin dapat melihat riwayat pengunjung yang melakukan konsultasi pada sistem.

Kebutuhan Non-Fungsional :

1. Ramah pengguna (User friendly)

2. Sistem dapat diakses dari perangkat komputer dengan menggunakan web browser.

Sistem memiliki fitur pemberithuan jika admin melakukan pengelolaan data, apakah pengelolaan berhasil atau ada kesalahan.

Sistem yang dikembangkan berupa aplikasi berbasis web. Web server dibutuhkan untuk menjalankan aplikasi tersebut. Data yang diolah sistem disimpan pada basis data. Server basis data juga dibutuhkan untuk menjalankan basis data yang digunakan sistem. Pengguna mengakses melalui web browser dengan memanggil URL aplikasi. Gambar 2 menunjukkan arsitektur sistem yang menjelaskan bagaimana sistem bekerja. 


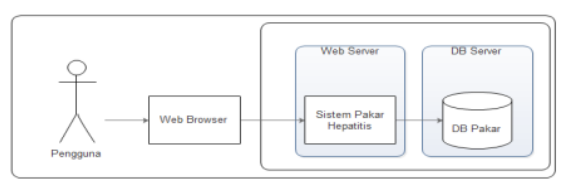

Gambar 2 Arsitektur Sistem Pakar Hepatitis

2. Desain

A. ERD

ERD digunakan untuk memodelkan data yang akan disimpan dalam basis data. Langkah yang dilakukan dalam merancang ERD adalah menentukan entitas yang ada, lalu entitas tersebut dihubungkan dalam notasi diagram.

Diagram yang menggambarkan keseluruhan sistem tersebut dapat menjelaskan semua data yang diolah sistem. Gambar 3 menunjukkan ERD keseluruhan sistem.

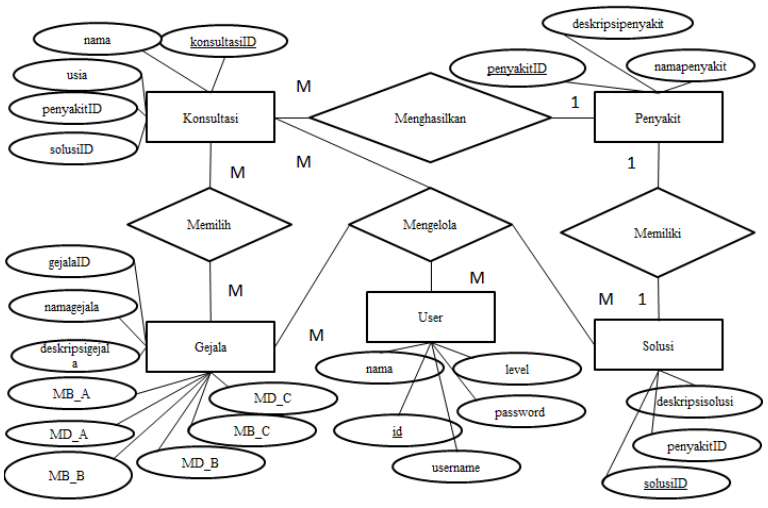

Gambar 3 ERD keseluruhan sistem

B. Diagram Aktivitas

Diagram aktivitas dibuat pada awal pemodelan UML untuk memeberikan perspektif mengenai proses yang dilakukan. Gambar 4 menunjukkan diagram aktivitas sistem yang dikembangkan.

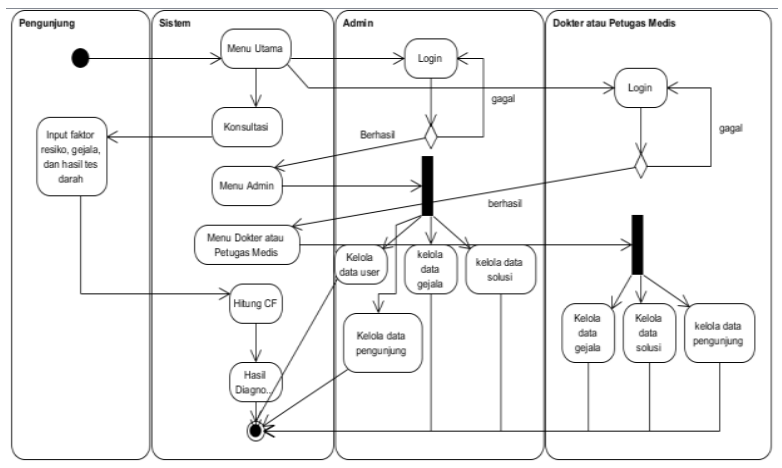

Gambar 4 Diagram Aktivitas

C. Diagram Use case

Bagaimana pengguna menggunakan sistem dapat digambarkan dengan diagram use case. Diagram use case dibuat berdasarkan skenario yang dilakukan pengguna ketika menggunakan fungsi sistem. Diagram use case dapat dilihat pada Gambar 5.

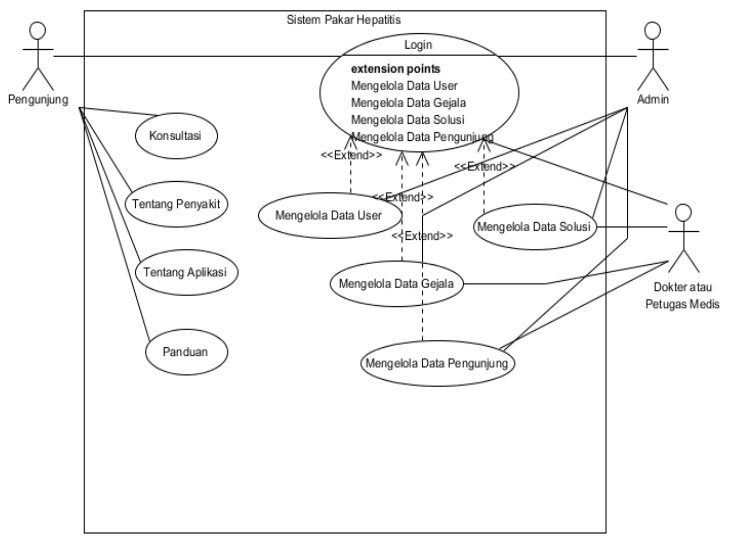

Gambar 5 Diagram use case

Dari diagram use case menunjukkan ada 3 jenis aktor. Aktor pengunjung adalah pengguna yang menggunakan sistem untuk keperluan konsultasi dan mencari informasi tentang penyakit. Aktor pengunjung dapat melakukan kegiatan konsultasi, melihat tentang penyakit, melihat tentang aplikasi, melihat panduan, dan melakukan login. Jika login berhasil pengguna merupakan aktor admin atau aktor dokter. Aktor admin dapat melakukan aktivitas admin seperti mengelola data user, mengelola data gejala, mengelola data solusi dan mengelola data pengunjung sedangkan aktor dokter atau ptugas medis tidak dapat mengelola data user.

D. Diagram Sekuensial

Diagram Sekuensial dibuat untuk mendapatkan gambaran perilaku sitem dalam mengeksekusi sebuah skenario. Gambar 6 menunjukkan gambar diagram sekuensial skenario konsultasi.

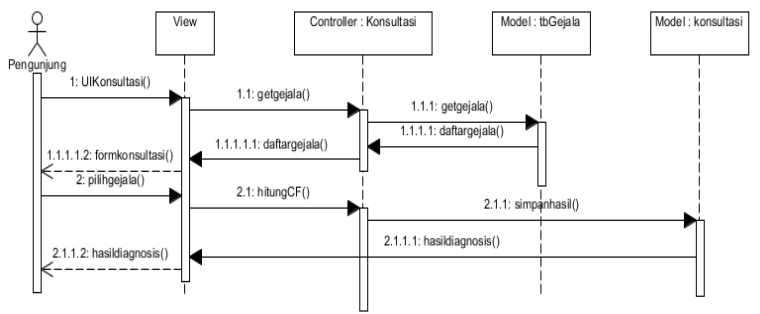

Gambar 6 diagram sekuensial skenario konsultasi

E. Diagram Kelas

Diagram kelas menunjukkan kelas dengan atribut yang saling terhubung satu sama lain. Kelas tersebut merupakan kelas dengan tipe model yang berfungsi sebagai abstraksi basis data. Semua model yang ada dikumpulkan pada sebuah kelas yang berfungsi sebagai penghubung dengan kelas tipe controller. Diagram kelas dapat dilihat pada Gambar 7. 

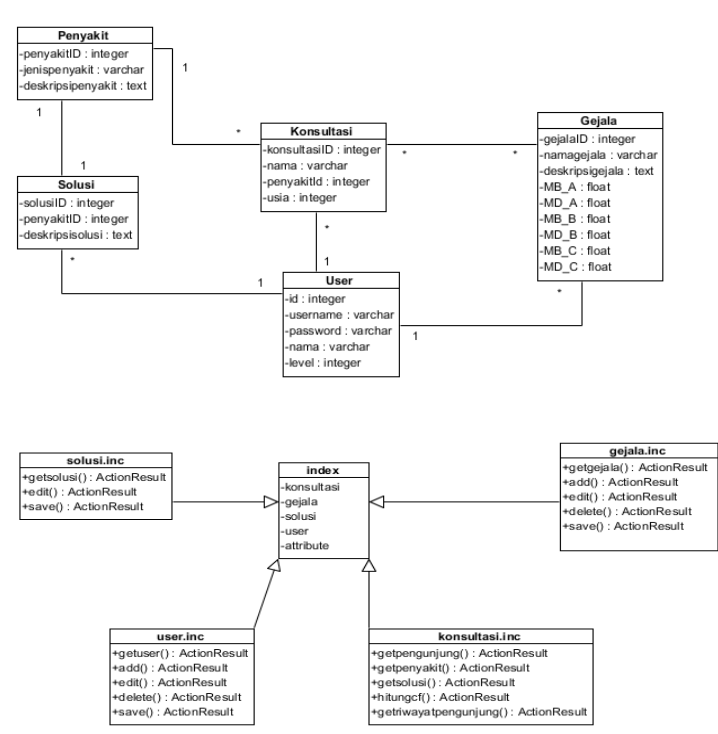

Gambar 7 Diagram Kelas sistem

\section{PENGUJIAN}

Pengujian Sistem Pakar Hepatitis dilakukan dengan menggunakan metode black-box. Pengujian ini dilakukan untuk menunjukkan fungsi program yang dibuat tentang cara operasi dan kegunaannya, apakah keluaran data sesuai dengan yang diharapkan. Pengujian ini dilakukan untuk mengetahui apakah masih terjadi kesalahan program atau program sudah berhasil diselesaikan dengan benar.

Pengujian aplikasi dibuat berupa tabel - tabel pengujian black-box dari masing-masing menu yang ada dalam aplikasi. Pengujian ini dibagi menjadi dua yaitu pengujian aktivitas pengunjung dan pengujian aktivitas admin

Tabel 1 Pengujian aktivitas pengunjung

\begin{tabular}{|l|l|}
\hline Pengujian & Analisis \\
\hline Menu utama & Berhasil \\
\hline $\begin{array}{l}\text { Menu tentang } \\
\text { penyakit }\end{array}$ & Berhasil \\
\hline $\begin{array}{l}\text { Menu cek } \\
\text { hepatitis }\end{array}$ & Berhasil \\
\hline Konsultasi & Berhasil \\
\hline
\end{tabular}

Tabel 2 Pengujian aktivitas admin

\begin{tabular}{|l|l|}
\hline Pengujian & Analisis \\
\hline Login & Berhasil \\
\hline Mengganti sandi & Berhasil \\
\hline Menu Manajemen User & Berhasil \\
\hline Tambah User & Berhasil \\
\hline Edit User & Berhasil \\
\hline Hapus User & Berhasil \\
\hline Menu Data Gejala & Berhasil \\
\hline Tambah Gejala & Berhasil \\
\hline Edit Gejala & Berhasil \\
\hline
\end{tabular}

\begin{tabular}{|l|l|}
\hline Hapus Gejala & Berhasil \\
\hline Menu Data Solusi & Berhasil \\
\hline Edit Solusi & Berhasil \\
\hline Menu Riwayat Pengunjung & Berhasil \\
\hline Hapus Pengunjung & Berhasil \\
\hline
\end{tabular}

Pengujian validasi ini dilakukan pada menu cek hepatitis. Pengujian yang dilakukan adalah menguji apakah hasil keluaran pada menu ini sudah sesuai. Untuk itu akan dibandingkan dengan perhitungan secara menual.

Berikut ini adalah studi kasus dietik dasar diagnosis hepatitis :

Seorang pasien bernama Tn. Dodi umur 46 tahun, bekerja sebagai guru SD. Berat badan Tn Dodi saat ini adalah $60 \mathrm{~kg}$ dengan tinggi badan $168 \mathrm{~cm}$. Pasien didiagnosa menderita hepatitis B. Hasil pemeriksaan laboratorium terakhir menunjukkan kadar SGOT $=58 \mathrm{U} / \mathrm{L}$ dan $\mathrm{SGPT}=78$ $\mathrm{U} / \mathrm{L}$, asamurat $=6,2 \mathrm{mg} / \mathrm{dl}$, albumin $=3,4 \mathrm{mg} / \mathrm{dl}$ dan hasil pemeriksaan $\mathrm{HBsAg}$ positif. Pasien mengeluh mual, sering pusing dan wajah terlihat pucat. Suhu tubuh pasien $37^{\circ} \mathrm{C}$, tekanan darah 120/80 mmHg.

Dari pernyataan diatas dapat diambil kesimpulan bahwa pasien bernama Dodi dengan umur 46 didiagnosa menderita hepatitis B. Hasil uji tes darah menunjukkan $\mathrm{SGOT}=58 \mathrm{U} / \mathrm{L}$ yang normalnya $3-45 \mathrm{U} / \mathrm{L}$ dan $\mathrm{SGPT}=78 \mathrm{U} / \mathrm{L}$ yang normalnya 0-35U/L. Pemeriksaan HBsAg positif. Gejala yang dialami mual, pusing atau yeri kepala, dan demam.

Pada pengujian form identitas akan diisi nama Dodi dengan umur 46, tidak ada faktor risiko yang dipilih, gejala yang dipilih adalah mual, nyeri kepala dan demam, dan uji tes darah yang dipilih adalah SGOT dan SGPT meningkat dan HBsAg positif. Gambar 8 menunjukkan pengujian dari studi kasus pasien Dodi saat mengisi form dan Gambar 9 menunjukkan pengujian memilih gejala.

Setelah tombol SUBMIT ditekan maka sistem akan menghitung nilai CF dan memberikan keluaran seperti yang ditunjukkan Gambar 10.

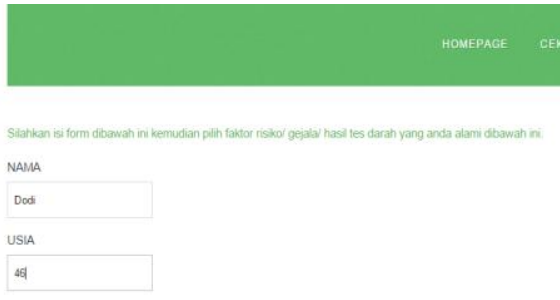

Gambar 8 Mengisi form konsultasi

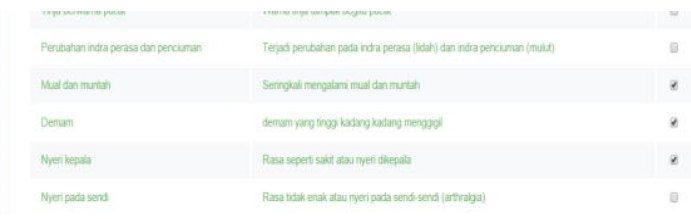




$$
\begin{array}{ll}
\mathrm{CFCB} & =\mathrm{CFB}_{\mathrm{g}}+\mathrm{CFB}_{\mathrm{t}}\left(1-\mathrm{CFB}_{\mathrm{g}}\right) \\
& =0.621331+0.8941(1-0.621331) \\
& =0.9598989529 \\
\text { Jadi CF B } & =0.9598989529 \\
\mathrm{CFCC} & =\mathrm{CFC}_{\mathrm{g}}+\mathrm{CFC}_{\mathrm{t}}\left(1-\mathrm{CFC}_{\mathrm{g}}\right) \\
& =0.27+0.56 *(1-0.27)=0.6788
\end{array}
$$

Jadi CF C $=0.6788$

Dari hasil perhitungan manual yang dilakukan diperoleh bahwa CF B paling besar dengan nilai $\mathrm{CF}=$ 0.9598989529. Hasil tersbut susai dengan pengujian pasien Dodi yang ditunjukkan pada Gambar 11. Maka dapat dikatakan bahwa keluaran sistem pakar untuk menu konsultasi sudah sesuai dengan rumus atau metode yang diterapkan.

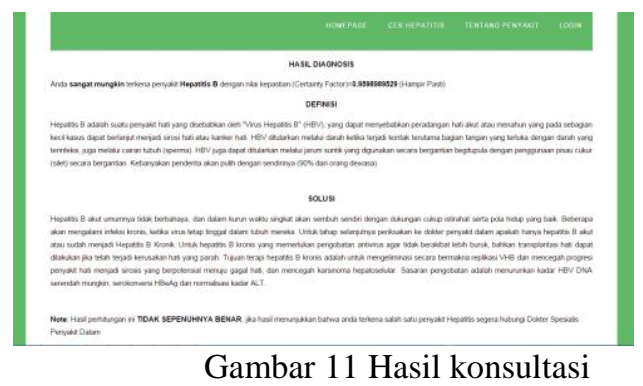

Setelah hasil keluar kemudian riwayat pasien Dodi yang berumur 46 dan didiagnosa terkena penyakit Hepatitis B akan disimpan pada menu Riwayat Pengunjung. Gambar 12 menunjukkan bahwa pengunjung yang sudah masuk kedalam basis data.

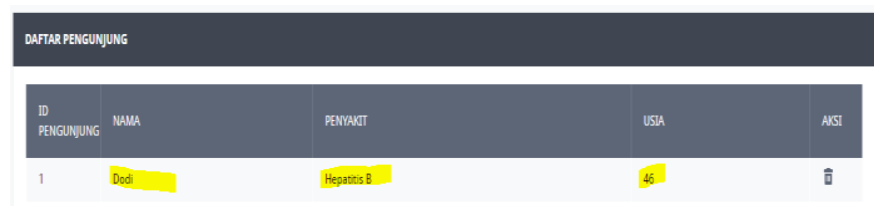

Gambar 12 Data yang masuk sesuai

Dari pengujian ini dapat diambil kesimpulan bahwa metode Certainty Factor dapat diterapkan untuk pengambilan keputusan dengan nilai kemungkinan suatu gajala sebagai acuannya tanpa menggunakan aturan (role) yang kompleks seperti metode forward chaining maupun backward chaining.

Metode penelusuran digunakan untuk diagnosis penyakit yang kompleks. Salah satu contoh penyakit yang kompleks adalah penyakit jantung. Ada beberapa penyakit jantung seperti Hipertensi, Gagal Jantung, Penyakit Katub Jantung, Penyakit Jantung Koroner, dan Aritmatia. Kelima penyakit tersebut memilik gejala yang hampir semuanya berbeda. Untuk itu metode yang digunakan adalah penulusuran forward chaining atau backward chaining dan juga dapat ditambahkan nilai kepastiannya menggunakan Certainty Factor.

Sistem dapat mengalami kegagalan atau salah diagnosis ketika masukan yang diberikan tidak sesuai dengan kenyataan yang dialami oleh calon pasien. Maka dari itu seharusnya yang melakukan pengisian faktor risiko, gejala, maupun hasil uji tes darah adalah Dokter atau Petugas Medis yang secara teknis paham mengenai penyakit Hepatitis tersebut.

\section{PENUTUP}

A. Kesimpulan

Kesimpulan dari penelitian Tugas Akhir ini diantaranya sebagai berikut.

1. Sistem sudah mampu mengeluarkan hasil diagnosis yang sama seperti diagnosis yang dilakukan oleh pakar.

2. Metode Certainty Factor dapat diterapkan pada sistem pakar dengan penyakit yang sederhana atau tidak kompleks, seperti dilakukan pada penyakit hepatitis pada penelitian ini.

B. Saran

Saran yang dapat diberikan oleh penulis adalah sebagai berikut.

1. Sistem dapat dikembangkan lebih lanjut menggunakan basis aturan yang lebih kompleks sehingga hasil diagnosis lebih akurat selain itu sistem juga dapat dikembangkan menggunakan metode pengambilan keputusan dan metode penelusuran yang lain.

2. Sistem Pakar ini memiliki banyak ruang untuk dikembangkan seperti integrasi dengan Sistem Rekam Medis dan juga dapat diintegrasikan dengan Sistem Pakar untuk penyakit dalam lainnya.

\section{DAFTAR PUSTAKA}

[1.] Kusumadewi, Sri, Artificial Intelligence (Teknik dan Aplikasinya), Yogyakarta, GRAHA ILMU, 2003.

[2.] Madcoms, Menguasai XHTML, CSS, PHP, \& MySQL melalui Dreamveaver, Yogyakarta, Andi, 2009.

[3.] Pramana, E. Rancang Bangun Aplikasi Diagnosa Penyakit Hepatitis Menggunakan Certainty Factor, Skripsi-S1, Sekolah Tinggi Manajemen Informatika dan Teknik Komputer, Surabaya, 2012.

[4.] P. DuBois., MySQL Cookbook, Second Ed, O’Reilly, 2006.

[5.] Sulaiman, Ali, Nurul Akbar, Laurentius A., Lesmana dan M. Sjaifoellah Noer, Buku Ajar Ilmu Penyakiy Hati, Semarang, Jaya Abadi, 2007.

[6.] Susanto, H., Aplikasi Diagnosis Penyakit Hepatitis Menggunakan J2ME Dengan Metode Certainty Factor, Skripsi-S1, Institut Teknologi Sepuluh November, Surabaya, 2009.

[7.] T.Sutojo, S.Si dkk., Kecerdasan Buatan, Yogyakarta, Andi, 2011. 